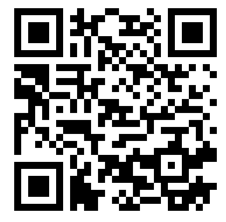

Submitted:

2019-08-10
Journal An-Nafs: Kajian Penelitian Psikologi

https://ejournal.iai-tribakti.ac.id/index.php/psikologi e-ISSN: 2549-6166 p-ISSN: 2528-0600

DOI: $10.33367 /$ psi.v5i1.878

Revised:

2019-11-18

Accepted:

2019-12-07

Published:

2020-06-01

\title{
MINDFUL-BASED COGNITIVE THERAPY (MBCT) DAN SELF-AWARENESS DALAM MENURUNKAN KECEMASAN IBU HAMIL PRIMIPARA
}

\author{
1Deacy Anindya Putri, ${ }^{2}$ Elly Yuliandari Gunatirin \\ ${ }^{1}$ deacy.putri@gmail.com, 2ellyyuliandari@gmail.com \\ Universitas Surabaya
}

\begin{abstract}
This study discusses the anxiety of primiparous pregnant women before delivery. Primiparous pregnant women are mothers who first have children, so anxiety often arises. Lack of Self-Awareness in primiparous pregnant women, especially those who experience anxiety has its impact. Self-awareness is the ability of a person to judge and place himself in certain conditions. This topic was taken because of the increasingly widespread anxiety in primiparous pregnant women, which resulted in less optimal pregnancy during the psychological impact. The method used in this study is a single case experiment. Giving Mindful-Based Cognitive Therapy (MBCT) is considered effective for reducing anxiety in primiparous pregnant women before delivery. The MBCT session that given relates to inner self-awareness, to increase the participant's self-awareness. Participants' anxiety was measured using the Pregnancy-Related Anxiety Scale (PRAS), while Self-Awareness would be measured using the Mindfulness Attention and Awareness Scale (MAAS). This study involved 2 participants who received intervention for 4 weeks. The results of the study were analyzed with trend analysis. As a result, both participants experienced decreased anxiety before delivery and increased self-awareness after getting MBCT intervention.
\end{abstract}

Keywords: Anxiety, MBCT, Primiparous, Self-Awareness

\begin{abstract}
Abstrak
Penelitian ini membahas kecemasan ibu hamil primipara menjelang persalinan. Ibu hamil primipara adalah ibu yang pertama kali memiliki anak, sehingga kecemasan sering kali muncul. Kurangnya Self-Awareness atau kesadaran diri pada ibu hamil primipara terutama yang mengalami kecemasan memiliki dampak tersendiri. Kesadaran diri merupakan kemampuan seseorang untuk menilai dan menempatkan dirinya pada kondisi tertentu. Penelitian ini penting dikarenakan semakin maraknya kecemasan pada ibu hamil primipara, yang mengakibatkan kurang optimalnya masa kehamilan yang berdampak pada psikologisnya. Metode yang digunakan pada penelitian ini adalah single case experiment. Pemberian Mindful-Based Cognitive Therapy (MBCT) dianggap efektif untuk menurunkan kecemasan pada ibu hamil primipara menjelang persalinan. Sesi MBCT yang diberikan berkaitan dengan inner self-awareness, sehingga dapat meningkatkan selfawareness partisipan. Kecemasan partisipan diukur dengan menggunakan PregnancyRelated Anxiety Scale (PRAS), sementara untuk Self-Awareness akan diukur dengan menggunakan Mindfulness Attention and Awareness Scale (MAAS). Penelitian ini melibatkan 2 partisipan yang mendapatkan intervensi selama 4 minggu. Hasil penelitian dianalisis dengan trend analysis. Hasilnya, kedua partisipan mengalami penurunan kecemasan menjelang persalinan dan self-awareness meningkat setelah mendapatkan intervensi MBCT.
\end{abstract}

Kata Kunci: Kecemasan, MBCT, Ibu Hamil Primipara, Self-Awareness 


\section{PENDAHULUAN}

Wanita ketika menyambut kehamilannya ada diantaranya yang merasa sangat cemas dan khawatir (Escott dkk., 2004). Timbulnya perasaan cemas menghadapi kelahiran pada ibu primipara sangat dipengaruhi oleh perubahan fisik selama masa kehamilan. Ibu primipara merupakan seorang ibu yang baru melahirkan pertama kali (Bobak, 2004). Darajat (dalam Pratiwi \& Suwarti, 2013), menjelaskan bahwa ada dua gejala kecemasan, yaitu psikologis (mental) dan fisiologis (fisik). Gejala psikologis adalah kecemasan sebagai gejala-gejala kejiwaan dengan ciri-ciri takut, tegang, bingung, khawatir, tidak dapat memusatkan perhatian, tidak berdaya, rendah hati, tidak tentram, ingin lari dari kenyataan hidup, perubahan emosi, turunnya kepercayaan diri, tidak ada motivasi, dan gelisah. Sementara gejala fisiologis (fisik), yaitu kecemasan yang sudah memengaruhi atau terwujud pada gejala-gejala fisik, terutama pada sistem saraf dengan ciri ujung jari terasa dingin, pencernaan tidak teratur, detak jantung cepat, keringat bercucuran, tekanan darah meningkat, tidur tidak nyenyak, nafsu makan hilang, kepada pusing, nafas sesak, dan mudah lelah.

Beberapa penelitian menunjukkan ibu hamil mengalami kecemasan atau depresi seperti hasil penelitian yang dilakukan oleh Adewuya dkk., (2006) pada sebuah populasi menunjukkan bahwa 39\% (172 wanita hamil) mengalami kecemasan dibandingkan dengan wanita yang tidak sedang hamil, yaitu hanya 16.3\% yang mengalami kecemasan. Kekhawatiran dan kecemasan yang dirasakan oleh wanita yang sedang mengandung apabila tidak ditangani dengan serius akan membawa dampak dan pengaruh buruk (Murni dkk., 2014). Penelitian yang dilakukan oleh Rubertsson dkk., (2014) menunjukkan bahwa kecemasan selama kehamilan sangat terkait dengan riwayat kecemasan di beberapa titik dalam kehidupan seorang wanita.

Menurut Mahmudah dalam penelitiannya (2011), persalinan merupakan saat yang sangat dinanti-nantikan oleh ibu hamil, terutama pada kehamilan pertama (primipara) agar dapat segera merasakan kebahagiaan melihat dan memeluk bayi yang telah dikandungnya selama beberapa bulan. Di sisi lain, terdapat hambatan-hambatan yang beresiko buruk bagi ibu dan janin dalam proses persalinan itu sendiri Ibu primipara dapat mengalami perasaan yang campur aduk seperti: bahagia, kecemasan, khawatir, takut karena belum pernah mengalami proses tersebut.

Faktor lain munculnya kecemasan adalah dari cara berpikir seseorang tentang sesuatu yang akan terjadi dan melihat permasalahan tersebut sebagai hal yang mengganggunya. Kecemasan kognitif merupakan rasa takut yang disadari dan meluas yang mengganggu kemampuan individu untuk berfikir jernih, memecahkan masalah dan 
memenuhi tuntuan lingkungannya. Wujud dari kecemasan kognitif adalah kebingungan, sulit berkonsentrasi, dan sulit mengingat sesuatu (Nurlaila, 2011). Menurut Mu'arifah (2012), pandangan teori kognitif menyimpulkan bahwa terjadinya kecemasan karena adanya pola pikir yang salah, atau terdistorsi atau tidak produktif (counterproductive) menyertai atau mendahului perilaku maladaptif dan gangguan emosional. Seseorang yang mengalami gangguan kecemasan cenderung menilai berlebihan (overestimate) terhadap bahaya dan kemungkinan bahaya situasi tertentu. Selain itu, cenderung menilai rendah (underestimate) terhadap kemampuan diri untuk mengatasi ancaman yang akan datang.

Kurangnya afirmasi pemikiran positif pada ibu hamil primipara juga dapat menjadi salah satu faktor kecemasan. Kesadaran diri atau self-awareness pada ibu hamil primipara merupakan hal yang diperlukan selama masa kehamilan. Self-awareness adalah kemampuan untuk mengetahui apa yang dirasakan dalam dirinya dan menggunakannya untuk memandu pengambilan keputusan diri sendiri, memiliki tolak ukur yang realistis atas kemampuan diri sendiri dan kepercayaan diri yang kuat (Goleman, 2003). Sementara menurut Aprillia (2017), Awareness menurut merupakan bentuk kesadaran yang dimiliki oleh setiap individu untuk selalu waspada terhadap segala sesuatu yang ada di sekitarnya. Hasil penelitian dari Fibriana dan Azinar (2016) saat memberikan kelas antenalan mengatakan, jika kesadaran ibu hamil untuk mengenali risiko yang dihadapi selama kehamilan dan kesadaran dalam mengenali terjadinya komlikasi persalinan masih rendah. Hal tersebut dapat memiliki dampak tersendiri bagi ibu hamil dan dampak terburuknya adalah kematian.

Tingkat kecemasan yang tinggi selama kehamilan memiliki dampak yang buruk bagi ibu dan bayi. Glover (2014) menjelaskan bahwa kecemasan yang parah memiliki dampak signifikan bagi keadaan biologis bayi baru lahir seperti tinggi badan, berat badan, dan lingkar kepala. Kecemasan pada awal kehamilan akan mengakibatkan keguguran, sementara pada trimester dua dan trimester tiga akan menyebabkan penurunan berat lahir bayi dan peningkatan aktivitas pada Hypothalamus-Hypophysis-Adrenal axis yang mengakibatkan perubahan steroidogenes, penghancuran perilaku sosial dan tingkat kesuburan di masa dewasa (Glover, 2014). Kecemasan berdampak negatif yang akan mengakibatkan munculnya berbagai keluhan fisik dan psikis yang akan mengganggu aktivitas sehari-hari. Bahkan menurut Grigoriadis dkk., (2011) kecemasan perinatal erat kaitannya dengan depresi.

Ada banyak alasan mengapa kehamilan dapat menyebabkan kerentanan meningkatnya kecemasan; hal ini termasuk perubahan fisiologis dan hormonal, ketidaknyamanan fisik, peningkatan stress, ketidakpastian, ketakutan mengenai 
kemungkinan kehamilan dan komplikasi kelahiran, kekhawatiran untuk kesehatan diri dan bayi, perubahan hidup yang signifikan, dan eksaserbasi atau pengulangan gangguan kejiwaan yang sudah ada sebelumnya (Wenzel, 2011). Selain itu O'Leary (2015) menjelaskan bahwa sumber stressor pada ibu hamil ini dapat berupa, misalnya, kekhawatiran tentang kesehatan dan kelahiran bayi, kekhawatiran tentang perubahan fisik, stres terkait pekerjaan, dan kurangnya dukungan sosial.

Penerimaan dukungan sosial bagi ibu hamil rupanya merupakan hal yang cukup penting dan signifikan. (Utomo \& Sudjiwanati, 2018) menjelaskan bahwa dukungan sosial yang diterima oleh ibu hamil akan berpengaruh dalam mengurangi kecemasan, karena pada saat itu ibu hamil yakin sudah memiliki banyak teman dan ada dukungan dari lingkungannya, maka keyakinan untuk dapat mengurangi kecemasan akan meningkat. Dukungan sosial terutama dari suami merupakan faktor utama yang berpengaruh terhadap terjadinya kecemasan pada ibu hamil dalam menghadapi masa kehamilan sampai persalinan. Beberapa bentuk dukungan suami yang sangat dibutuhkan oleh ibu hamil antara lain, pelayanan yang baik, menyediakan transportasi atau dana untuk biaya konsultasi, dan menemani berkonsultasi ke dokter ataupun bidan sehingga suami dapat mengenali tanda-tanda komplikasi kehamilan dan juga kebutuhan ibu hamil (Diani \& Susilawati, 2013).

Terdapat beberapa intervensi dari beberapa penelitian yang dapat dilakukan untuk mengurangi kecemasan yang dirasakan oleh ibu primipara. Selain intervensi dengan terapi, obat psikotropika seperti antidepressants dan benzodiazepines sering pula digunakan untuk mengobati kecemasan, namun hal tersebut berisiko pada perkembangan janin (Hayes dkk., 2012; Udechuku dkk., 2010). Di sisi lain pun wanita sering enggan untuk meminum antidepressants dan obat-obatan psikotropika lainnya karena kekhawatiran terhadap fetal dan komplikasi pada bayi (Grigoriadis dkk., 2011). Hal tersebut membuat perlunya pertimbangan pemberian intervensi non-pharmacological kepada ibu hamil (Dennis dkk., 2017). Salah satu intervensi non-pharmacological yang dapat digunakan adalah Mindfulness-Based Cognitive Therapy (MBCT). Penemuan pada systematic review baru baru ini mengindikasikan potensi manfaat dari intervensi mindfulness pada kesejahteraan wanita terutama untuk menurunkan tingkat dampak buruk, depresi, dan kecemasan selama kehamilan (Matvienko-Sikar dkk., 2016). Penelitian yang telah dilakukan oleh Evans, dkk (2008) menunjukkan bahwa subjek dalam penelitian tersebut mengalami penurunan kecemasan, ketegangan, kekhawatiran, dan gejala depresi mereka yang signifikan setelah mengikuti program MBCT selama 8 minggu. Satu alasan untuk menguji perawatan baru untuk Generalized Anxiety Disorder (GAD) terkait dengan fakta 
Deacy Anindya Putri \& Elly Yuliandari Gunartirin | Mindful-Based Cognitive Therapy

bahwa meskipun beberapa terapi efektif, persistensi dari gejala GAD adalah permasalahannya. Secara konseptual, masuk akal jika pengembangan dari mindfulness pada individu yang memiliki GAD akan mendapatkan manfaat karena mindful state atau keadaan dasar menangkap kualitas kesadaran yang dikarakteristikan oleh kemurnian dan kejelasan pengalaman.

MBCT merupakan adaptasi dari Mindfulness-Based Stress Reduction (MBSR) yang dikembangkan oleh Segal, Williams, dan Teasdale (2018). MBCT mengintegrasikan aspek CBT dengan MBSR dan juga ditawarkan dalam format grup delapan sesi selama 8 minggu. MBCT mengajarkan meditasi mindfulness sebagai praktik terapi inti dengan teknik kognitif untuk menargetkan gejala spesifik dari disfungsi psikologis. Dalam penelitian Goodman, Guarino, Chenausky, dkk (2014) juga menjelaskan bahwa MBCT dalam intervensi CALM Pregnancy memiiliki potensi untuk memberikan pengobatan non-pharmacological yang efektif untuk wanita hamil yang mengalami kecemasan.

Dalam penelitian yang dilakukan oleh Goodman, Guarino, Chenausky, dkk (2014) menjelaskan bahwa terdapat beberapa alasan MBCT mungkin dapat digunakan secara khusus untuk pengobatan sub-klinis. Pada penelitian CALM Pregnancy menjelaskan bahwa dari hasil studi percontohan dan tingkat klinis Generalized Anxiety Disorder (GAD) pada wanita hamil: (1) wanita sangat menyukai intervensi non-pharmacological selama kehamilan. (2) Ruminasi adalah hal yang utama yang terjadi pada GAD. MBCT telah membuktikan telah mengurangi ruminasi yang maladaptif (Heeren \& Philippot, 2011; Michalak dkk., 2011). (3) Sifat khawatir dalam GAD adalah masa depan yang diarahkan oleh karena itu pelatihan saat ini difokuskan pada mindful awareness yang mungkin dapat memberikan alternatif yang bermanfaat untuk merespon individu dengan GAD (Roemer \& Orsillo, 2006). 4) Individu dengan GAD memiliki kesulitan dalam regulasi emosi, seperti yang ditunjukkan oleh reaktivitas negatif yang lebih besar dan pemahaman emosi yang buruk (Mennin dkk., 2005; Tull dkk., 2009). (5) Individu dengan GAD biasanya memiliki pola terhibituasi untuk menghindari pengalaman internal yang menyedihkan (Orsillo \& Roemer, 2011).

Intervensi berbasis mindfulness atau kesadaran memungkinkan pengembangan kemampuan yang penting bagi ibu hamil dan ibu baru (Hall dkk., 2015). Selain itu, intervensi tersebut menjanjikan dalam mengatasi sejumlah permasalahan seperti deperesi dan kecemasan antenatal, membuat wanita hamil lebih berdaya dan kepuasan dalam persalinan (Fisher dkk., 2012). Intervensi ini mendorong praktik dari kesadaran dan penerimaan pemikiran, emosi, dan sensasi tubuh seseorang, membangun toleransi terhadap stress, mengurangi reaktivitas dan menghindari pengalaman yang tidak 
menyenangkan. Tujuh faktor sikap yang mencakup dalam intervensi berbasis kesadaran meliputi non-judging, kesabaran, pikiran pemula, kepercayaan, non-striving, penerimaan dan melepaskan (Kabat-Zinn, 1991). Penjelasan tersebutlah yang membuat penelitian ini menggunakan MBCT sebagai bentuk intervensi yang akan diberikan kepada wanita hamil, terutama primipara.

Berdasarkan penjelasan di atas, pada penelitian ini ingin melihat pengaruh dari pemberian MBCT pada ibu hamil yang mengalami kecemasan dalam menghadapi proses persalinan. Ibu hamil yang dimaksud dalam penelitian ini adalah ibu yang baru pertama kali akan melahirkan atau biasa disebut dengan ibu primipara.

\section{METODE}

Metode penelitian ini adalah single case experiment. Desain penelitian ini adalah AB-A, yaitu akan ada dua kali pengukuran pada baseline dan satu kali pengukuran intervensi. Desain ini dipilih untuk mengukur kondisi kecemasan ibu hamil sebelum intervensi, saat proses intervensi, dan setelah proses intervensi selesai.

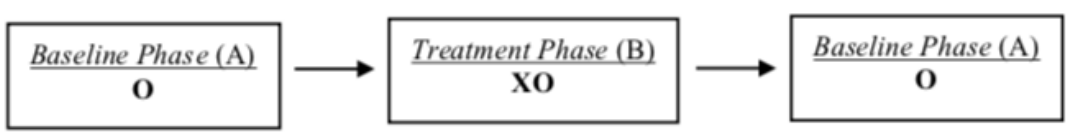

Gambar 1. Desain Penelitian

Pengumpulan data dilakukan dengan cara wawancara dan penyebaran kuesioner. Wawancara yang dilakukan, sesuai dengan panduan yang tertera pada Anxiety Status Inventory (ASI). Sementara kuesioner yang digunakan adalah Pregnancy-Related Anxiety Scale (PRAS) yang merupakan alat ukur yang digunakan untuk melihat kecemasan secara spesifik pada ibu hamil, The Mindfulness Attention and Awareness Scale (MAAS) digunakan untuk menilai karakteristik inti dari perhatian disposisional, yaitu: keterbukaan atau penerimaan perhatian dan perhatian terhadap apa yang sedang terjadi di masa saat ini, dan Neo-Five Factor Inventory (NEO-FFI). Neo-FFI adalaha alat ukur yang disusun oleh Costa dan McCrae (1989) dengan tujuan memetakan gambaran jenis kepribadian seseorang. Partisipan yang akan mengikuti penelitian ini harus memiliki kriteria: ibu primipara dengan kehamilan pada trimester 3, tidak pernah keguguran (baik disengaja maupun tidak), tidak ada permasalahan riwayat medis yang dapat mengganggu proses kehamilan hingga persalinan), memperoleh skor kecemasan minimal sedang, tinggal hanya dengan suami sebagai support system terdekat, pendidikan minimal SMA, usia 20-30 tahun dan berprofesi sebagai ibu rumah tangga.

Teknik analisis data yang digunakan pada penelitian ini adalah trend analysis. Trend yang dilihat adalah perkembangan kecemasan dari partisipan selama baseline phase 
dan treatment phase. Data-data yang didapatkan pada penelitian ini akan dipetakan ke dalam grafik trend untuk melihat perubahan pada masing-masing fase. Analisis tren merupakan analisis grafikal yang membandingkan grafik tren baseline phase dan treatment phase.

\section{PAPARAN HASIL}

Pada penelitian ini, terdapat hasil asesmen dan hasil setelah dilakukan intervensi terhadap partisipan. Hasil penelitian dianalisa menggunakan analisis tren. Terdapat tiga fase yang berbeda, yaitu baseline phase (1), treatment phase, dan baseline phase (2). Pada grafik yang ditampilkan akan ada tiga garis analisis tren yaitu, garis skor mentah (berwarna biru), garis skor median (berwarna merah) dan garis putus-putus yang menghubungkan antara skor baseline phase (1) dengan baseline phase (2) (berwarna hitam). Terdapat dua partisipan yang mengikuti serangkaian intervensi yang diberikan. Berikut adalah penjelasannya:

\section{Subjek Mawar}

Aspek Childbirth Concerns. Aspek ini mengukur kecemasan seorang wanita hamil terhadap proses persalinannya. Dapat dilihat dari garis grafik baseline phase 1 hingga baseline phase 2, nampak adanya penurunan kecemasan. Kondisi ini dapat ditunjang dari style of well-being Mawar yang tergolong Upbeat Optimists. Mawar memandang proses persalinan yang dihadapinya akan berjalan dengan baik. Setelah melalui proses persalinan, Mawar merasa lebih tenang karena persalinan berjalan lancar. Mawar dapat mengontrol cukup dirinya selama proses persalinan. Mawar juga menceritakan jika dirinya masih dapat diajak berbicara walaupun dalam kondisi kesakitan karena kontraksi.

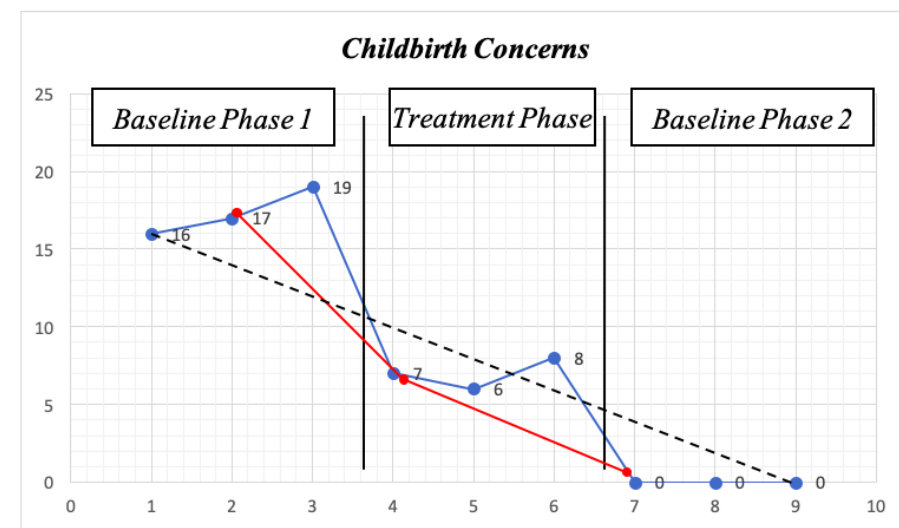

Gambar 2. Analisis tren Mawar pada Aspek Childbirth Concerns

Aspek Body Image Concerns. Selama masa kehamilan, Mawar tidak terlalu memperhatikan perubahan bentuk tubuhnya. Perubahan skor median Mawar pada aspek ini tidak signifikan dari masa kehamilan hingga persalinan berakhir. Karakteristik Mawar 
yang tergolong relaxed, Mawar tidak akan mengeluarkan tenaga besar untuk mempermasalahkan perubahan kondisi fisiknya. Pada dasarnya, Mawar terlalu concern pada bentuk tubuhnya baik saat hamil bahkan setelah melahirkan.

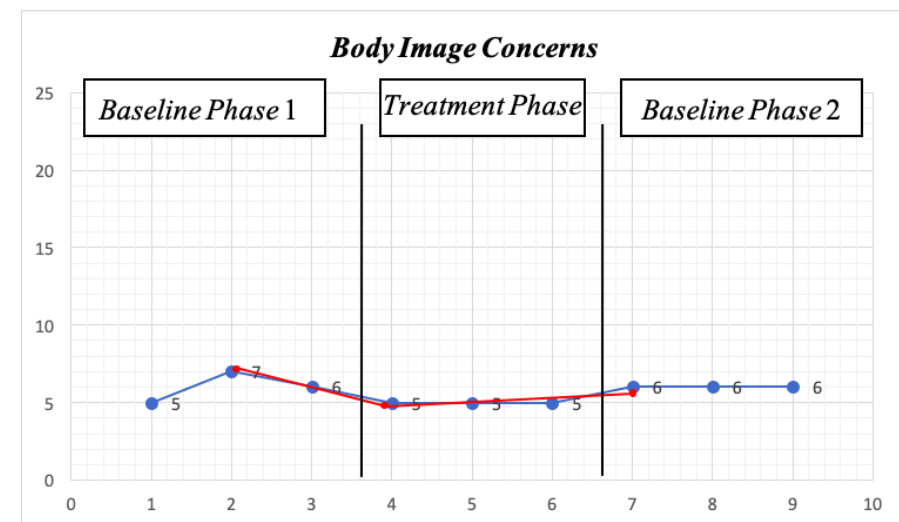

Gambar 3. Analisis tren Mawar pada Aspek Body Image Concerns

Aspek Attitudes Towards Childbirth. Aspek ini mengukur kesiapan mental partisipan menjelang proses persalinan. Menurunnya skor mentah pada aspek ini, juga ditunjang dari dukungan sosial dari suami Mawar. Kehadiran suami Mawar merupakan dukungan yang dibutuhkan oleh Mawar dan selalu didapatkan oleh Mawar. Mawar merasakan suaminya selalu ada untuk Mawar terlebih lagi selama masa kehamilan ini.

Skor mentah Mawar mengalami penurunan dari baseline phase 1 ke treatment phase. Dapat dilihat pula pada garis median juga mengalami penurunan. Hal ini menunjukkan jika pemberian MBCT berpengaruh menurunkan kecemasan Mawar pada aspek ini.

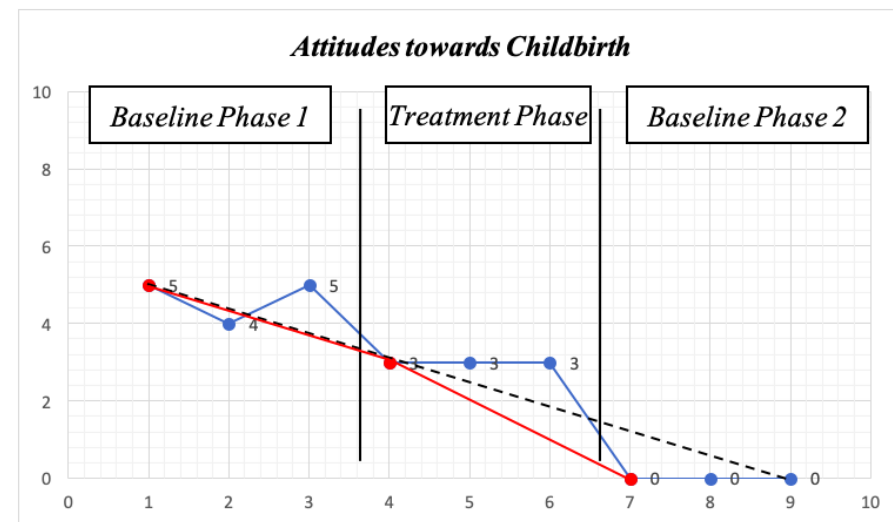

Gambar 4. Analisis tren Aspek Attitudes Towards Childbirth Mawar

Aspek Worry About Motherhood. Peran sebagai ibu merupakan pengalaman pertama bagi Mawar. Kecemasannya terhadap peran barunya sebagai ibu, sempat menunjukkan adanya penurunan skor median pada saat intervensi. Adanya penurunan skor ini dikarenakan pemberian intervensi yang konsisten dan Mawar melakukan intervensi secara mandiri pula, terlepas dari jadwal pertemuan dengan peneliti. Setelah 
proses persalinan selesai, peran baru Mawar pun dimulai. Berdasarkan hasil wawancara. Mawar mengaku jika masih beradaptasi dengan peran barunya sebagai ibu. Peran baru ini ternyata tidak mudah bagi Mawar, terlebih lagi ASI-nya sempat tidak keluar selama 1 minggu. Hal ini memicu kembali munculnya kecemasan pada aspek ini.

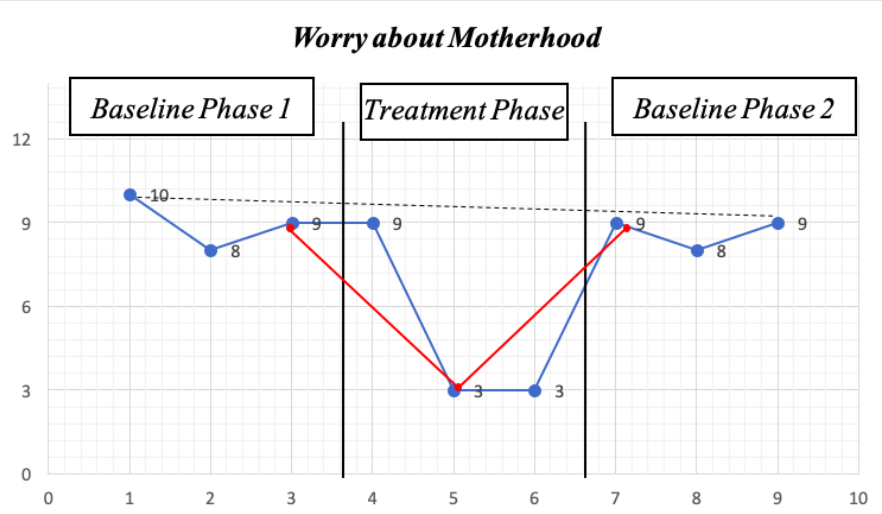

Gambar 5. Analisis tren Aspek Worry About Motherhood Mawar

Aspek Acceptance of Pregnancy. Dapat dilihat jika skor mentah baseline phase 1 ke treatment phase sangat konsisten. Sejak mengetahui kehamilannya, Mawar dan suami sangat menantikan kehadiran anak pertamanya ini. Pemberian MBCT tidak nampak berpengaruh pada aspek ini. Hal ini dikarenakan kondisi Mawar yang sudah optimal dalam penantian kehadiran anak pertama.

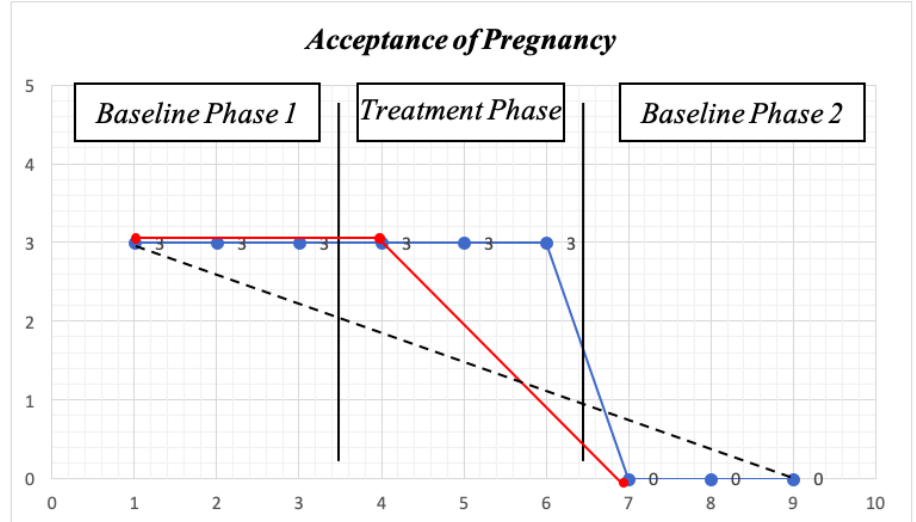

Gambar 6. Analisis tren Acceptance of Pregnancy Mawar

Aspek Anxiety Indicators. Skor mentah cukup fluktuatif dari baseline phase 1 hingga baseline phase 2. Skor mentah dari baseline phase 1 menurun di treatment phase, namun kembali meningkat pada baseline phase 2. Skor median juga menunjukkan hasil yang fluktuatif dari kondisi Mawar sebelum diberikan intervensi, ketika diberikan intervensi dan setelah intervensi selesai diberikan. Hal ini menunjukkan jika MBCT efektif diberikan untuk menurunkan gejala kecemasan, namun ketika intervensi dihentikan gejala kecemasan dapat muncul kembali. Kondisi ini dapat dikatakan berhubungan dengan aspek worry about motherhood yang juga mengalami peningkatan setelah Mawar 
melahirkan. Selain itu, karakteristik Mawar yang memiliki Neuroticism yang tergolong sedang juga dapat memicu kembali munculnya kecemasan pada Mawar.

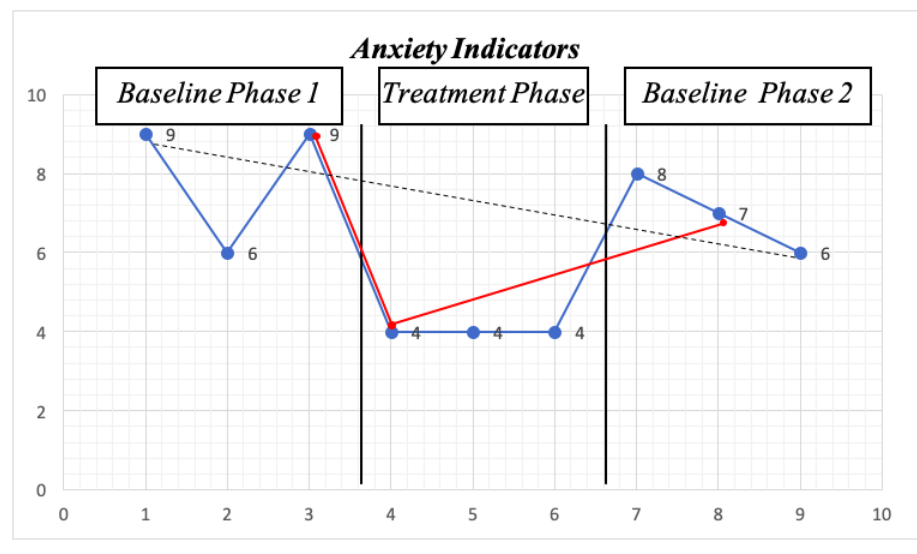

Gambar 7. Analisis tren Anxiety Indicators Mawar

Aspek Attitudes Towards Medical Staff. Setelah memutuskan untuk melakukan persalinan di bidan, Mawar memiliki kecemasan terkait pelayanan yang nantinya akan didapatkannya. Mawar mencemaskan apakah akan mendapatkan pelayanan yang tepat dan dapat bersalin dengan normal. Kecemasan ini kemudian menurun pada proses intervensi, dengan menunjukkan skor median yang menurun (gambar 8). Terjadinya penurunan ini dapat mengindikasikan pemberian intervensi efektif untuk menurunkan kecemasan.

Ditambah lagi, saat proses persalinan ternyata pelayanan bidan atau tenaga medis dirasa baik oleh Mawar. Bidan memberikan pertolongan dan menyiapkan segala sesuatu yang dibutuhkan oleh Mawar, serta berusaha untuk membantu Mawar melahirkan dengan normal. Kondisi tersebut menunjukkan pula adanya dukungan dari bidan. Dukungan yang didapatkan Mawar dari bidan membuat Mawar merasa aman dan yakin jika dirinya dapat bersalin dengan normal.

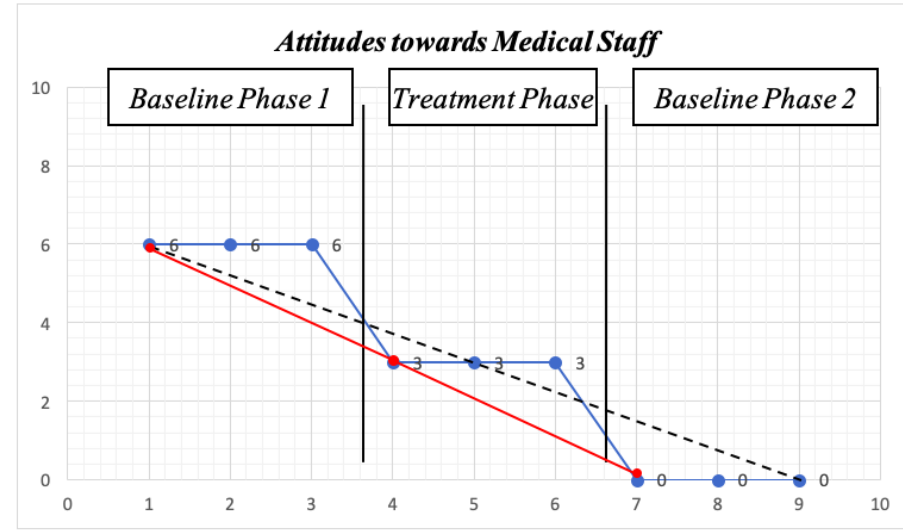

Gambar 8. Analisis tren Aspek Attitudes Towards Medical Staff 
Aspek Avoidance. Aspek menjelaskan apakah ada perilaku menghindar dari proses persalinan normal dan lebih memilih persalinan secara sesar. Pemilihan proses sesar dilakukan untuk untuk mengurangi kecemasannya. Pada baseline phase 1, skor mentah Mawar nampak lebih tinggi dibandingkan skor mentah pada treatment phase. Hal ini menunjukkan kecemasan Mawar terhadap proses persalinan normal menurun, sehingga Mawar tidak melakukan penghindaran terhadap proses persalinan tersebut. Berdasarkan hasil wawancara sebelumnya, Mawar memang menginginkan untuk persalinan normal. Oleh karena itu, dapat dikatakan jika pemberikan MBCT berpengaruh untuk mengurangi kecemasan pada aspek ini.

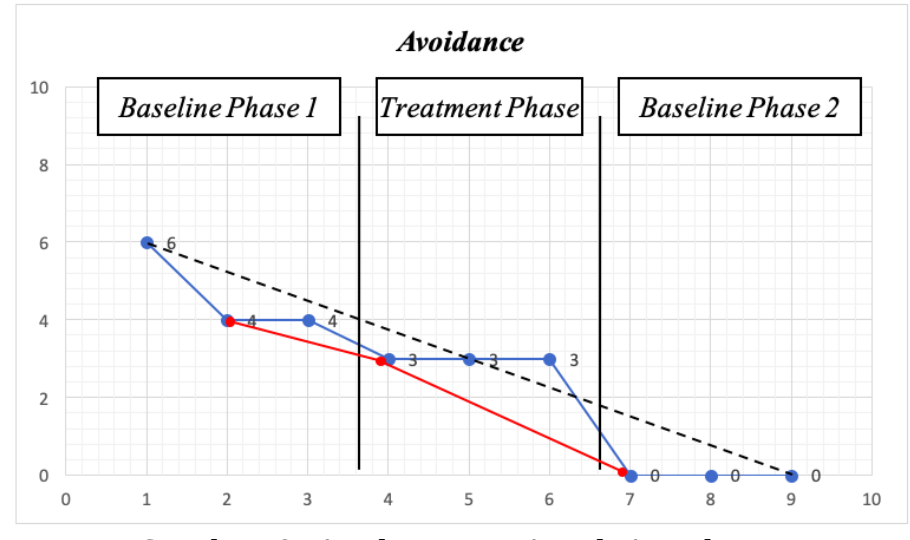

Gambar 9. Analisis tren Aspek Avoidance

Aspek Baby Concerns. Sesuai dari gambar 9, diketahui skor mentah pada baseline phase 1 hingga baseline phase 2 menurun cukup drastis. Hal ini menunjukkan jika adanya penurunan kecemasan terkait kondisi fisik dan kesehatan Mawar pada bayi-nya. Kondisi demikian dapat diartikan jika intervensi MBCT yang diberikan efektif untuk menurunkan kecemasan pada aspek ini. Selain itu setelah melalui proses persalinan, Mawar telah bertemu langsung dengan bayi-nya dalam keadaan sempurna sehingga kecemasan tentang kondisi fisik sudah berkurang.

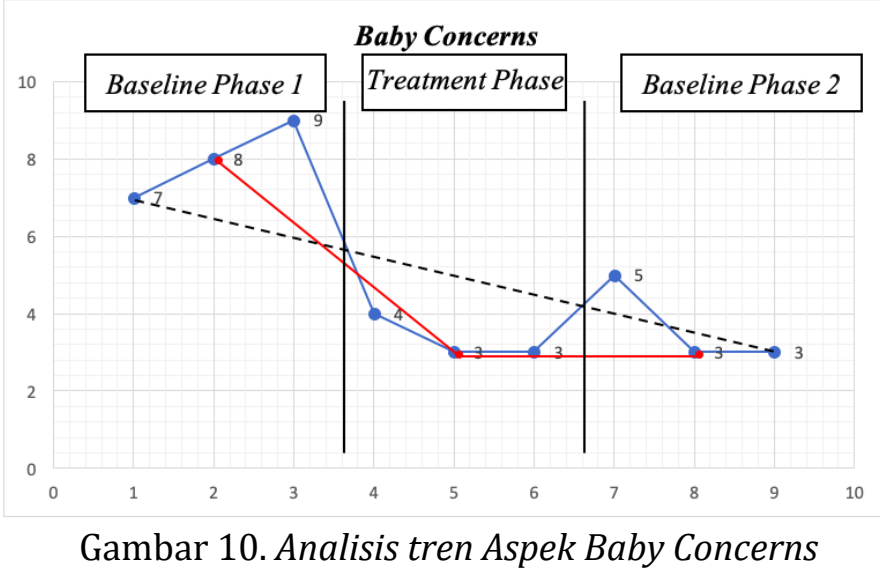


Deacy Anindya Putri \& Elly Yuliandari Gunartirin| Mindful-Based Cognitive Therapy

\section{MAAS (Mawar)}

Dapat dilihat adanya peningkatan skor mentah dari baseline phase 1 ke treatment phase. Setelah adanya peningkatan skor di treatment phase, terjadi penurunan skor mentah di baseline phase 2. Kondisi tersebut menggambarkan, tingkat kesadaran atau mindfull Mawar meningkat ketika diberikan intervensi dan selama proses intervensi. Setelah intervensi diberikan, tingkat kesadaran atau mindfull kembali menurun lagi.

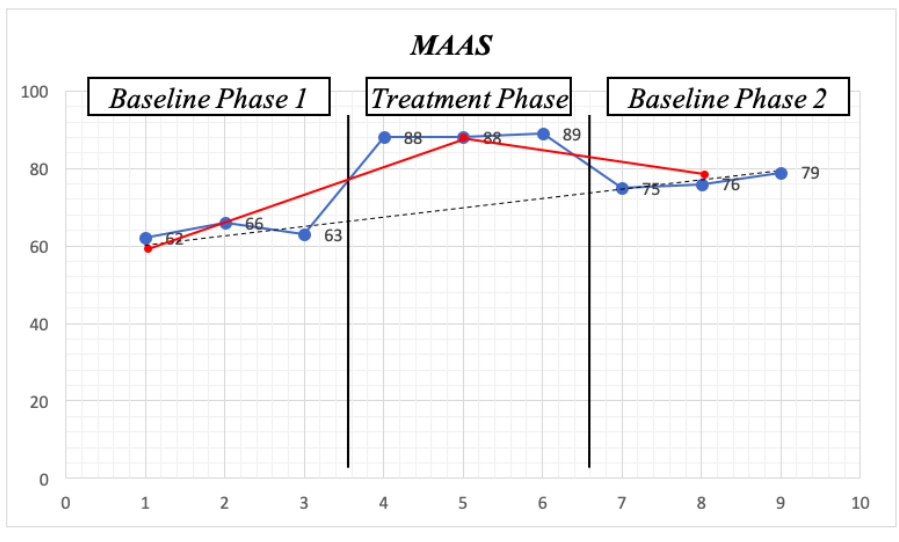

Gambar 11. Analisis tren MAAS Mawar

Berdasarkan hasil wawancara pada saat follow-up, Mawar mengaku tidak melakukan kegiatan mindfull-nya mendekati persalinan dan sesudah persalinan. Padahal, konsistensi melakukan mindful secara mandiri dapat membantu partisipan untuk menjaga efek positif dari intervensi. Faktor kondisi setelah melahirkan pun dapat menjadi pemicu turunnya tingkat kesadaran Mawar. Mawar cukup kewalahan menjalani peran barunya sebagai ibu. Terlebih lagi, anaknya sempat sakit dan ASI Mawar tidak keluar selama seminggu. Di sisi lain, support system Mawar yang utama, yaitu suaminya, mengalami demam berdarah yang mengahruskannya opname. Hal tersebut membuat sang suami tidak dapat hadir menemani Mawar pada awal pasca melahirkan.

\section{Subjek Melati}

Aspek Childbirth Concerns. Pada gambar 11 nampak skor median Melati mengalami penurunan dari baseline phase 1 ke treatment phase. Hal ini menunjukkan jika kecemasan Melati terkait dengan proses persalinannya mengalami penurunan. 


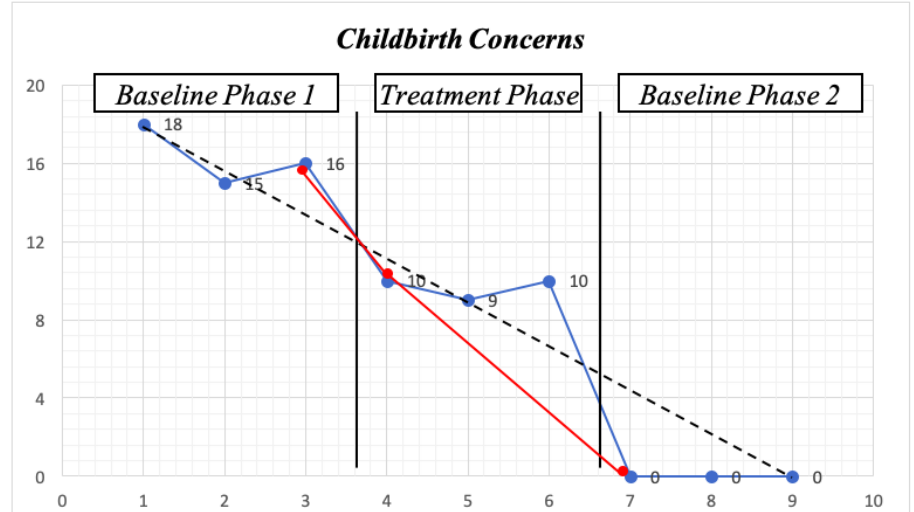

Gambar 12. Analisis tren Aspek Childbirth Concerns Melati

Pengukuran pada baseline phase 2, dilakukan dengan wawancara. Ketakutan Melati tidak dapat menahan rasa sakit pada saat proses persalinan ternyata tidak seperti yang dibayangkannya. Melati dapat melalui proses persalinan dengan baik, walaupun jadwal persalinannya tidak sesuai dengan yang seharusnya.

Aspek Body Image Concerns. Pada aspek ini, terlihat kecemasan Melati menurun dan konsisten. Hal tersebut dapat dilihat dari skor median baseline phase 1 yang menurun pada treatment phase dan skor tersebut konsisten hingga baseline phase 2. Kecemasan Melati terkait dengan kondisi fisik atau bentuk tubuhnya berkurang setelah mendapatkan intervensi MBCT.

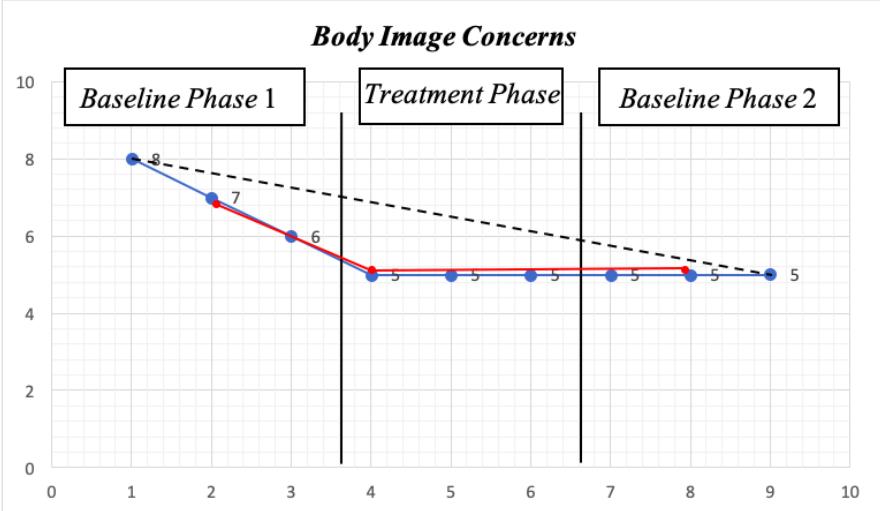

Gambar 13. Analisis tren Aspek Body Image Concerns Melati

Aspek Attitudes Towards Childbirth. Melati mengalami penurunan kecemasan. Skor baseline phase 1 mengalami penurunan pada treatment phase. Kondisi demikian menggambarkan jika kesiapan mental Melati untuk menghadapi proses persalinan semakin optimal.

Di sisi lain, dapat dikatakan jika pemberikan intervensi MBCT mempengaruhi peningkatan kesiapan Melati menjelang proses persalinan. Pada pengukuran baseline phase 2 yang dilakukan dengan wawancara, Melati mengungkapkan jika dirinya dapat menahan rasa sakit ketika mendapatkan suntikan bius. 


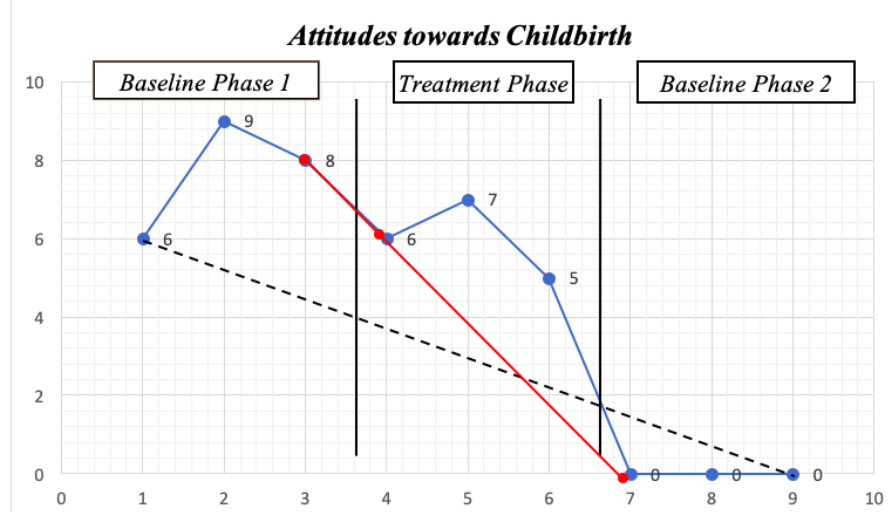

Gambar 14. Analisis tren Aspek Attitudes Towards Childbirth Melati

Aspek Worry About Motherhood. Skor mentah Melati cukup fluktuatif dari baseline phase 1 , treatment phase sampai baseline phase 2. Meski demikian, skor mediannya mengalami penurunan dari baseline phase 1 hingga baseline phase 2 . Hal ini dapat menggambarkan jika, ada penurunan kecemasan Melati pada aspek ini.

Skor mentah dari treatment phase ke baseline phase tidak terlalu mengalami penurunan yang berarti dikarenakan efek intervensi yang hilang dan peran baru Melati saat ini. Perannya sebagai ibu baru yang membuat Melati terkadang masih merasa kurang optimal. Terlebih lagi Melati masih merasa belum dapat memahami arti tangisan dari bayinya.

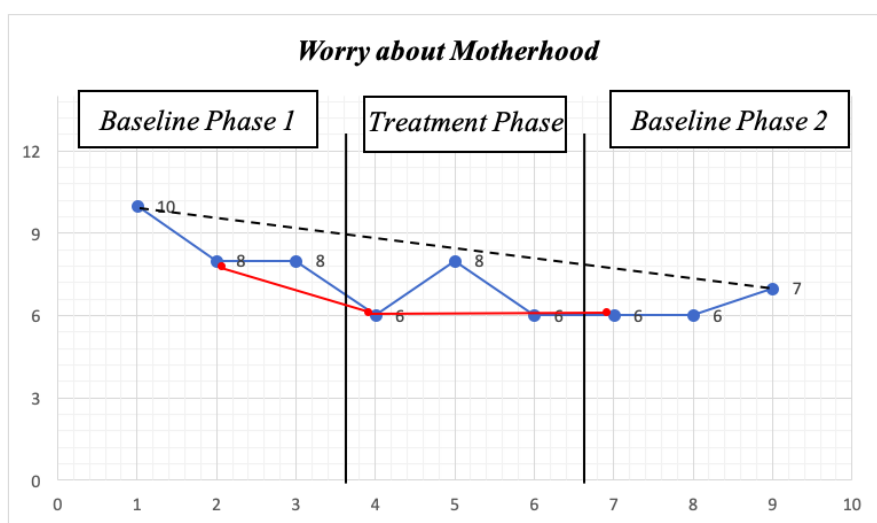

Gambar 15. Analisis tren Aspek Worry About Motherhood Melati

Aspek Acceptance of Pregnancy. Sesuai dengan grafik di atas, dapat dilihat jika skor mentah dan skor median Melati pada aspek ini tidak mengalami perubahan apa pun dari baseline phase 1 ke treatment phase 2. Hal ini dikarenakan, Melati memang sudah sangat menanti kehamilan pertamanya setelah 1 tahun lebih pernikahannya.

Pada baseline phase 2, diberikan skor 0 karena tidak dapat diukur secara kuantitatif. Meskipun demikian, sangat jelas terlihat dari raut wajah Melati yang sangat bahagia atas kehadiran putra pertamanya. 


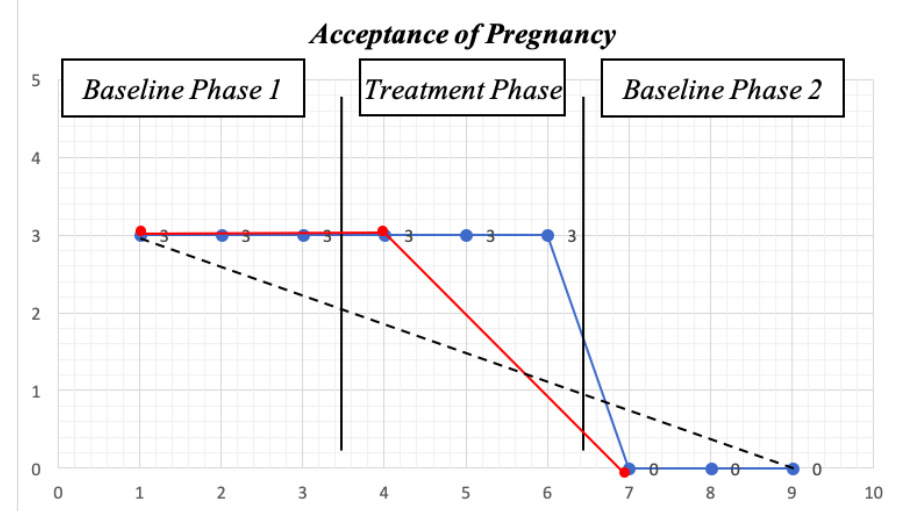

Gambar 16. Analisis tren Aspek Acceptance of Pregnancy

Aspek Anxiety Indicators. Melati mengalami penurunan gejala kecemasan. Dilihat dari skor mentah baseline phase 1 hingga baseline phase 2 mengalami penurunan. Hal ini menunjukkan jika pemberian MBCT berpengaruh terhadap penurunan gejala kecemasan Melati mejelang persalinan pertamanya.

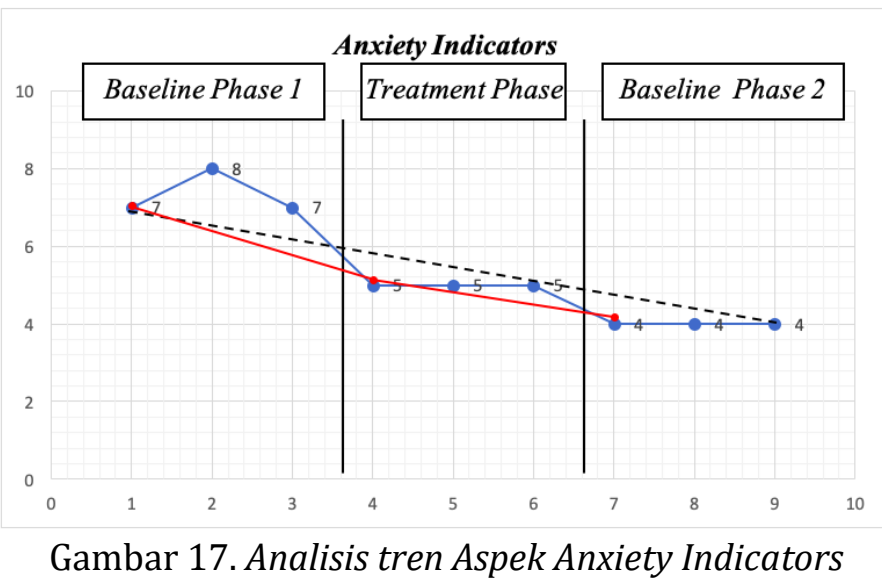

Aspek Attitudes Towards Medical Staff. Terjadi penurunan skor mentah dari baseline phase 1 ke treatment phase. Begitu pula skor median yang juga mengalami penurunan pada aspek ini. Hal ini menunjukkan jika Melati mengalami penurunan kecemasan terhadap pelayanan tenaga medis.

Pada baseline phase 2 diukur melalui wawancara. Melati mengungkapkan jika sebenarnya dirinya sedikit kecewa dengan dokter kandungannya yang tidak dapat menangani proses persalinannya. Pelayanan yang diberikan dari pihak rumah sakit ternyata juga tidak sesuai dengan ekspektasi. Suster yang menanganinya dianggap terlalu santai, sehingga Melati sempat sedikit panik. Meskipun panik, namun Melati mengaku sempat melakukan 3 minutes breathing space untuk menenangkannya. 


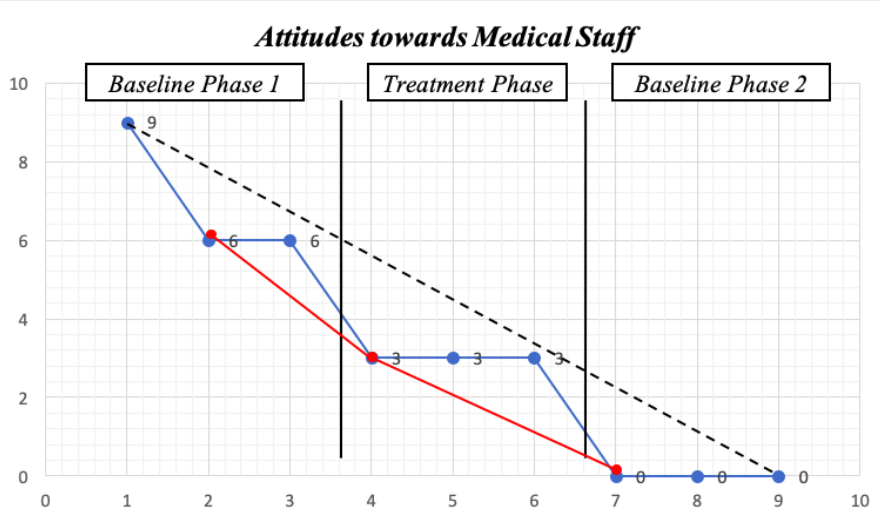

Gambar 18. Analisis tren Attitudes Towards Medical Staff Melati

Aspek Avoidance. Skor median Melati dari baseline phase 1 ke treatment phase 2 konstan. Sementara skor mentah Melati mengalami peningkatan dari baseline phase 1 ke treatment phase 2. Hal ini dapat diartikan jika Melati memiliki pertimbangan untuk melakukan persalinan secara sesar dan menghindari persalinan normal. Sesuai dengan kondisi Melati, dokter kandungannya memang menyarankan Melati untuk melakukan persalinan secara sesar. Saran tersebut atas dasar adanya kista yang dimiliki oleh Melati. Sehingga wajar, jika Melati memilih sesar. Pada situasi ini bukan atas dasar penghindaran, melainkan saran dari dokter kandungan Melati.

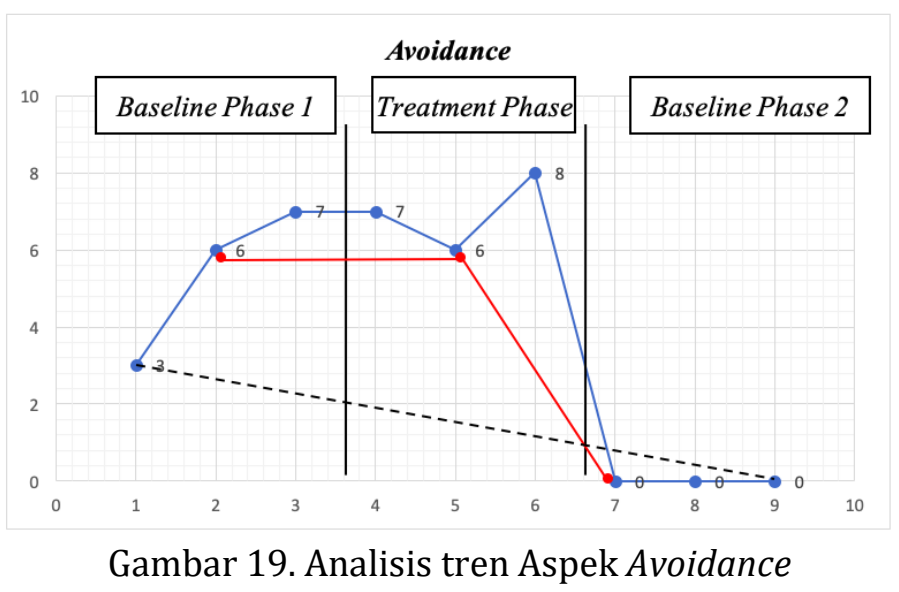

Aspek Baby Concerns. Terdapat penurunan kecemasan pada aspek Baby Concerns pada Melati. Kondisi tersebut dapat dilihat dari skor mentah baseline phase 1 ke treatment phase yang mengalami penurunan dan skor tersebut konisisten hingga baseline phase 2 . Hal ini menunjukkan jika Melati kecemasan Melati terkait dengan kesehatan dan kondisi fisik bayinya telah menurun. Oleh karena itu dapat dikatakan jika MBCT berpengaruh terhadap penurunan kecemasan pada aspek Baby Concerns. 


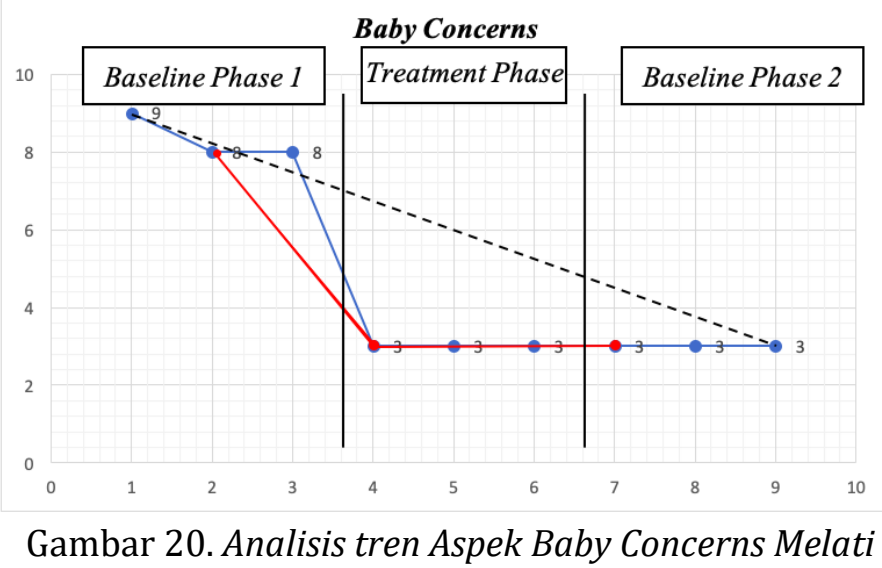

\section{MAAS (Melati)}

Berdasarkan pada gambar 20, tingkat kesadaran Melati mengalami peningkatan. Hal tersebut dapat dilihat dari garis median yang mengalami kenaikan. Skor median naik dari baseline phase 1 ke treatment phase dan konsisten hingga ke baseline phase 2, walaupun skor mentah Melati cukup fluktuatif. Kondisi tersebut menunjukkan jika pemberikan intervensi MBCT memberikan pengaruh untuk meningkatkan kesadaran pada Melati

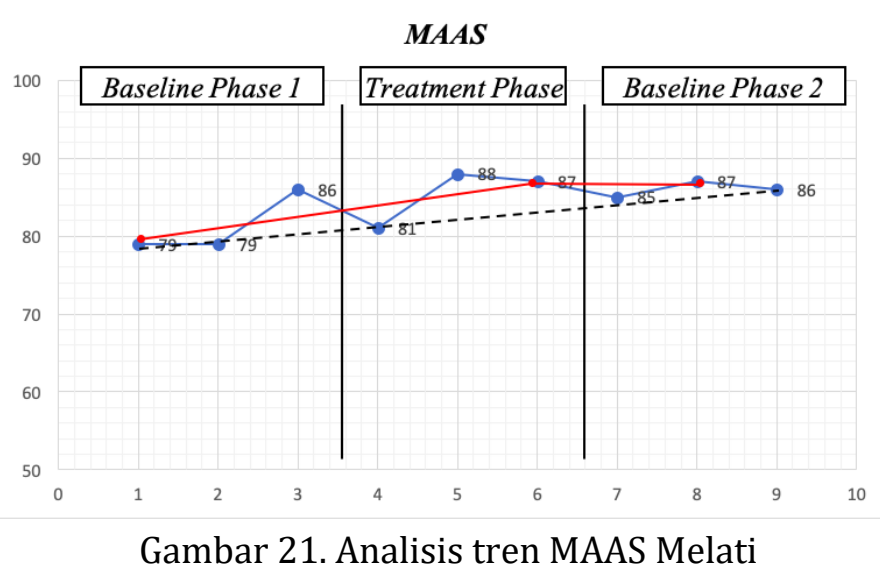

\section{Observasi}

Adapun hasil observasi yang dilakukan kepada kedua partisipan adalah sebagai berikut Ketiga aspek tersebut didapatkan dari hasil observasi. Observasi dilakukan dengan panduan indikator kecemasan DSM V, sebagai berikut: 
Tabel 01: Hasil Observasi

\begin{tabular}{|c|c|c|c|c|}
\hline \multirow[b]{2}{*}{ Indikator } & \multirow[b]{2}{*}{ Deskripsi } & \multicolumn{3}{|c|}{ Kemunculan } \\
\hline & & $\begin{array}{c}\text { Hari } \\
\text { I }\end{array}$ & $\begin{array}{c}\text { Hari } \\
\text { II }\end{array}$ & $\begin{array}{c}\text { Hari } \\
\text { III }\end{array}$ \\
\hline \multirow[t]{5}{*}{ Gejala Fisik } & $\begin{array}{l}\text { 1. Terlihat tegang, lesu, tidak } \\
\text { bersemangat, gemetaran, menangis, } \\
\text { berkeringat. }\end{array}$ & 3 & 2 & 5 \\
\hline & 2. Bolak-balik toilet untuk buang air & 0 & 2 & 1 \\
\hline & $\begin{array}{l}\text { 3. Melakukan } \\
\text { berulang yang tidak perlu secara } \\
\text { terus menerus }\end{array}$ & 10 & 12 & 9 \\
\hline & $\begin{array}{l}\text { 4. Saat berbicara, nafas menjadi } \\
\text { pendek atau terengal-engal. }\end{array}$ & 4 & 6 & 9 \\
\hline & $\begin{array}{l}\text { 5. Mulut terlihat kering dan muka } \\
\text { tampak merah. }\end{array}$ & 0 & 0 & 2 \\
\hline \multirow[t]{4}{*}{ Gejala emosional } & 1. Terlihat gelisah, cemas atau takut. & 2 & 2 & 3 \\
\hline & $\begin{array}{l}\text { 2. Mudah marah, kesal, sedih saat } \\
\text { menceritakan sesuatu }\end{array}$ & 4 & 4 & 6 \\
\hline & $\begin{array}{l}\text { 3. Menangis saat menceritakan } \\
\text { sesuatu. }\end{array}$ & 0 & 0 & 0 \\
\hline & $\begin{array}{l}\text { 4. Banyak mengucapkan } \\
\text { kalimat nalimat- } \\
\text { ketidakmampuan diri, atau } \\
\text { menyalahkan diri sendiri: } \\
\text { a. "aku tidak yakin dengan diriku" } \\
\text { b. "aku kesal, aku marah" } \\
\text { c. "aku takut, aku cemas" } \\
\text { d. "aku tidak tahu apa yang harus } \\
\text { dilakukan, seperti ingin berhenti } \\
\text { saja" } \\
\text { e. "aku merasa gagal" dan lain-lain. }\end{array}$ & 7 & 7 & 6 \\
\hline \multirow[t]{6}{*}{ Gejala kognitif } & $\begin{array}{lll}\text { 1. Sulit untuk } & \text { fokus } & \text { atau } \\
\text { berkonsentrasi } & \text { pada } & \text { saat } \\
\text { pelaksanaan aktivitas asesmen } & \\
\end{array}$ & 2 & 4 & 2 \\
\hline & 2. Sulit fokus pada saat pembicaraan. & 0 & 0 & 0 \\
\hline & $\begin{array}{l}\text { 3. Berbicara tidak jelas atau terbata- } \\
\text { bata saat menceritakan sesuatu. }\end{array}$ & 0 & 2 & 2 \\
\hline & $\begin{array}{l}\text { 4. Sulit untuk menceritakan atau tidak } \\
\text { mau menceritakan sesuatu. }\end{array}$ & 2 & 1 & 1 \\
\hline & $\begin{array}{l}\text { 5. Berkata "lupa/tidak ingat" saat akan } \\
\text { menceritakan sesuatu. }\end{array}$ & 0 & 2 & 1 \\
\hline & 6. Pikiran menjadi kosong (melamun) & 0 & 0 & 0 \\
\hline
\end{tabular}

\section{PEMBAHASAN}

Setelah kedua partisipan mengikuti keseluruhan rangakaian kegiatan MBCT, kecemasan yang dialami keduanya mengalami penurunan selama pemberian intervensi. Terdapat beberapa aspek di dalamnya mengalami perubahan dan tidak mengalami perubahan. Dari total 9 aspek yang diukur, pemberian MBCT dapat menurunkan kecemasan pada aspek childbirth concerns, attitudes towards childbirth, attitudes towards medical staff, avoidance, dan baby concerns. Sementara pada aspek body images concerns 
dan acceptance of pregnancy tidak mengalami perubahan yang signifikan. Hal ini dikarenakan, kedua partisipan tidak terfokuskan pada perubahan bentuk tubuh. Jika dilihat, perubahan bentuk tubuh dari kenaikan berat badan kedua peserta tidak terlalu banyak sehingga tidak membuat keduanya cemas.

Pasangan dari kedua partisipan pun tidak pernah membicarakan terkait perubahan bentuk tubuh mereka. Kedua partisipan juga sangat menantikan anak pertama mereka, sehingga tentu saja mereka sangat menerima kehamilan pertamanya. Berikutnya, adapun aspek yang fluktuatif setelah diberikan MBCT yaitu worry about motherhood dan anxiety indicators. Pada kedua aspek tersebut, terlihat menunjukan penurunan kecemasan selama menjalani proses intervensi. Berbeda lagi ketika proses intervensi telah selesai diberikan. Berdasarkan hasil follow-up, setelah melawati masa postpartum, peran partisipan menjadi ibu membutuhkan waktu untuk beradaptasi. Terlebih kondisi setelah melahirkan pada kedua peserta yang tidak sesuai dengan ekspektasi. Misalnya saja, partisipan Mawar, ASInya tidak keluar selama seminggu dan suami yang opname. Sementara pada Melati, beberapa hari setelah anak di lahirkan, terkena flu dan kuning sehingga harus diopname. Kondisi tersebut membuat memicu munculnya gejela kecemasan dan kecemasan apakah mereka dapat menjadi ibu yang sesuai dengan keinginan anaknya atau tidak.

Pada penelitian ini, meditasi yang paling mudah dilakukan oleh peserta adalah 3 minutes breathing space. Meditasi tersebut tidak memerlukan waktu yang panjang dan instruksi cenderung singkat. Pada penelitian sebelumnya, belum ada yang membahas secara detail sesi mana atau kegiatan mana yang lebih mudah dilakukan oleh partisipan. Sementara pada kegiatan body scanning, nampak partisipan mengerahkan energi lebih besar. Body scanning merupakan kegiatan meditasi yang pertama. Pada kegiatan itu partisipan benar-benar diminta untuk mengenali sensasi apa saja yang muncul pada dirinya. Reaksi kedua partisipan setelah melakukan body scanning adalah berkeringat, ngos-ngosan, dan badan terasa ringan. Menurut Effendi (2006) salah satu reaksi tubuh setelah melakukan meditasi adalah tubuh serasa melayang. Setelah beristirahat sejenak dan minum air putih kondisi tubuh kembali netral dan lebih relaks. Maka dari reaksi yang dimunculkan paritisipan dapat terbilang wajar, karena sebelumnya mereka belum pernah melakukan meditasi.

Intervensi berbasis mindfulness atau kesadaran memungkinkan pengembangan kemampuan yang penting bagi ibu hamil dan ibu baru (Hall dkk., 2015). Selain itu, intervensi tersebut menjanjikan dalam mengatasi sejumlah permasalahan seperti deperesi dan kecemasan antenatal, membuat wanita hamil lebih berdaya dan kepuasan dalam 
persalinan (Fisher dkk., 2012). Secara keseluruhan, pemberian MBCT kepada kedua partisipan mampu memberikan pengaruh terhadap kecemasan yang dialami. Pengaruh tersebut berupa penurunan kecemasan menjelang persalinan dan meningkatkan kesadaran atau mindfull kepada kedua partisipan. Seperti halnya yang dilakukan Evans dkk, (2008) menunjukkan bahwa subjek dalam penelitian tersebut mengalami penurunan kecemasan, ketegangan, kekhawatiran, dan gejala depresi mereka yang signifikan setelah mengikuti program MBCT. Penemuan pada systematic review telah mengindikasikan potensi manfaat dari intervensi mindfulness pada kesejahteraan wanita terutama untuk menurunkan tingkat dampak buruk, depresi, dan kecemasan selama kehamilan (Matvienko-Sikar dkk., 2016).

Selain itu, kedua partisipan menunjukkan adanya peningkatan tingkat kesadaran. Hal tersebut dapat dilihat dari skor awal baseline phase 1 hingga baseline phase 2 (Gambar 11 dan gambar 21), keduanya masuk dalam kategori "baik" dari yang sebelumnya "cukup". Terapi menggunakan mindfulness, membutuhkan kemampuan untuk fokus dan memberikan perhatian serta kesadaran penuh. Berbekal dengan taraf kecerdasan yang memadai kedua partisipan menjadi salah satu faktor yang membuat tingkat kesadaran kedua partisipan meningkat. Brown dan Ryan (2003) mempertegas bahwa mindfulness didasari oleh meningkatnya keadaan sadar terjaga (awareness) yang terus-menerus memonitor keadaan diri dan lingkungan luar; dan adanya perhatian (attention) yang memusat sehingga menghasilkan kesadaran penuh akan pengalamannya secara lebih terbuka.

\section{SIMPULAN}

Secara keseluruhan kecemasan yang dirasakan oleh kedua partisipan menjelang proses persalinan pertama termasuk kategori sedang. Dari sisi kepribadian, kedua partisipan memiliki tipe kepribadian pencemas dalam taraf yang sedang. Tipe kepribadian Mawar yang menonjol adalah Agreeableness, yaitu seseorang yang patuh dengan aturanaturan yang berlaku dan mudah mengikuti perkataan orang lain. Jika kondisi yang dialaminya tidak sesuai dengan yang seharusnya, maka akan memicu kecemasannya. Sementara tipe kepribadian Melati yang menonjol adalah Consciousness, menggambarkan seseorang yang senang dengan keteraturan. Jika kondisi yang dihadapinya tidak sesuai dengan tahapan yang berlaku maka bisa memicu kecemasan.

Saat pemberian MBCT, kecemasan partisipan menurun menjelang persalinan. Meski demikian, pada aspek Anxiety Indicators dan Worry about Motherhood berpotensi untuk mengalami kecemasan kembali tergantung dari kondisi partisipan setelah 
Deacy Anindya Putri \& Elly Yuliandari Gunartirin | Mindful-Based Cognitive Therapy

melahirkan. Hal ini masih perlu dilakukan penelitian lebih lanjut terhadap faktor-faktor lain yang memungkinkan memunculkan kecemasan pada aspek tersebut. pemberian intervensi secara konsisten akan lebih memberikan hasil yang efektif hingga fase postpartum.

Dari hasil observasi indikator kecemasan yang muncul pada gejala fisik kecemasan adalah adanya perilaku berulang, buang air kecil, dan berbicara seperti terengal-engal. Sementara gejala emosional adalah partisipan mudah marah, sedih dan berkali-kali mengeluarkan kata atau kalimat negatif. Gejala kognitifnya, terkadang kehilagan fokus, sulit untuk bercerita tentang kehamilannya, dan mengatakan "lupa/ tidak ingat" ketika akan menceritakan sesuatu.

\section{UCAPAN TERIMA KASIH}

Terima kasih saya ucapkan Tuhan YME, yang telah memberikan ridho-Nya kepada saya hingga dapat melakukan penelitian hingga tuntas. Kepada rekan-rekan yang membantu saya dalam melakukan penelitian ini. Tentu saja tak lupa saya ucapkan terima kasih atas kerjasama yang diberikan partisipan saya selama penelitian ini.

\section{DAFTAR PUSTAKA}

Adewuya, A. O., Ola, B. A., Aloba, O. O., \& Mapayi, B. M. (2006). Anxiety disorders among Nigerian women in late pregnancy: A controlled study. Archives of Women's Mental Health, 9(6), 325-328. https://doi.org/10.1007/s00737-006-0157-5

Aprillia, Y. (2017). Bebastakut Hamil dan Melahirkan: Panduan Praktis Persalinan yang Nyaman dan Minim Trauma. PT. Gramedia Pustaka Utama.

Bobak, I. M.; L. (2004). Buku Ajar Keperawatan Maternitas Edisi 4 (Jakarta). EGC. //stikesmajapahit.ac.id/opac/index.php?p=show_detail\&id=108

Brown, K. W., \& Ryan, R. M. (2003). The benefits of being present: Mindfulness and its role in psychological well-being. Journal of Personality and Social Psychology, 84(4), 822-848. https://doi.org/10.1037/0022-3514.84.4.822

Dennis, C.-L., Falah-Hassani, K., \& Shiri, R. (2017). Prevalence of antenatal and postnatal anxiety: Systematic review and meta-analysis. The British Journal of Psychiatry: The Journal of Mental Science, 210(5), 315-323. https://doi.org/10.1192/bjp.bp.116.187179

Diani, L. P. P., \& Susilawati, L. K. P. A. (2013). Pengaruh Dukungan Suami terhadap Istri yang Mengalami Kecemasan pada Kehamilan Trimester Ketiga di Kabupaten Gianyar. Jurnal Psikologi Udayana, https://doi.org/10.24843/JPU.2013.v01.i01.p01

Efendi, M. (2006). Pengantar Psikopedagogik anak berkelainan. Bumi Aksara. 
Escott, D., Spiby, H., Slade, P., \& Fraser, R. B. (2004). The range of coping strategies women use to manage pain and anxiety prior to and during first experience of labour. Midwifery, 20(2), 144-156. https://doi.org/10.1016/j.midw.2003.11.001

Evans, S., Ferrando, S., Findler, M., Stowell, C., Smart, C., \& Haglin, D. (2008). Mindfulnessbased cognitive therapy for generalized anxiety disorder. Journal of Anxiety Disorders, 22(4), 716-721. https://doi.org/10.1016/j.janxdis.2007.07.005

Fibriana, A. I., \& Azinar, M. (2016). Model Kelas Ibu Hamil untuk Pemetaan Risiko Kehamilan dan Pencegahan Komplikasi Persalinan. Jurnal Abdimas, 20(1), 11-1818.

Fisher, C., Hauck, Y., Bayes, S., \& Byrne, J. (2012). Participant experiences of mindfulnessbased childbirth education: A qualitative study. BMC Pregnancy and Childbirth, 12(1), 126. https://doi.org/10.1186/1471-2393-12-126

Glover, V. (2014). Maternal depression, anxiety and stress during pregnancy and child outcome; what needs to be done. Best Practice \& Research. Clinical Obstetrics \& Gynaecology, 28(1), 25-35. https://doi.org/10.1016/j.bpobgyn.2013.08.017

Goleman, D. (2003). Kecerdasan emosi untuk mencapai puncak prestasi (A. T. K. Widodo, Penerj.). Gramedia Pustaka Utama.

Goodman, J. H., Guarino, A., Chenausky, K., Klein, L., Prager, J., Petersen, R., Forget, A., \& Freeman, M. (2014). CALM Pregnancy: Results of a pilot study of mindfulnessbased cognitive therapy for perinatal anxiety. Archives of Women's Mental Health, 17(5), 373-387. https://doi.org/10.1007/s00737-013-0402-7

Grigoriadis, S., de Camps Meschino, D., Barrons, E., Bradley, L., Eady, A., Fishell, A., Mamisachvili, L., Cook, G. S., O’Keefe, M., Romans, S., \& Ross, L. E. (2011). Mood and anxiety disorders in a sample of Canadian perinatal women referred for psychiatric care. Archives of Women's Mental Health, 14(4), 325-333. https://doi.org/10.1007/s00737-011-0223-5

Hall, H., Beattie, J., Lau, R., East, C., \& Biro, M. (2015). The effectiveness of mindfulness training on perinatal mental health; a systematic review. Integrative Medicine Research, 4, 125. https://doi.org/10.1016/j.imr.2015.04.233

Hayes, R. M., Wu, P., Shelton, R. C., Cooper, W. O., Dupont, W. D., Mitchel, E., \& Hartert, T. V. (2012). Maternal antidepressant use and adverse outcomes: A cohort study of 228,876 pregnancies. American Journal of Obstetrics and Gynecology, 207(1), 49.e19. https://doi.org/10.1016/j.ajog.2012.04.028

Heeren, A., \& Philippot, P. (2011). Changes in Ruminative Thinking Mediate the Clinical Benefits of Mindfulness: Preliminary Findings. Mindfulness, 2(1), 8-13. https://doi.org/10.1007/s12671-010-0037-y

Kabat-Zinn, J. (1991). Full catastrophe living: Using the wisdom of your body and mind to face stress, pain, and illness /. Pub. by Dell Publishing, a division of Bantam Doubleday Dell Pub. Group. 
Deacy Anindya Putri \& Elly Yuliandari Gunartirin | Mindful-Based Cognitive Therapy

Mahmudah, D. (2011). Hubungan dukungan keluarga dan religiustas dengan kecemasan melahirkan pada ibu hamil anak pertama Primigravida). http://repository.uinjkt.ac.id/dspace/handle/123456789/4698

Matvienko-Sikar, K., Lee, L., Murphy, G., \& Murphy, L. (2016). The effects of mindfulness interventions on prenatal well-being: A systematic review. Psychology \& Health, 31(12), 1415-1434. https://doi.org/10.1080/08870446.2016.1220557

McCrae, R. R., \& Costa, P. T. (1989). More reasons to adopt the five-factor model. American Psychologist, 44(2), 451-452. https://doi.org/10.1037/0003-066X.44.2.451

Mennin, D. S., Heimberg, R. G., Turk, C. L., \& Fresco, D. M. (2005). Preliminary evidence for an emotion dysregulation model of generalized anxiety disorder. Behaviour Research and Therapy, 43(10), 1281-1310. https://doi.org/10.1016/j.brat.2004.08.008

Michalak, J., Hölz, A., \& Teismann, T. (2011). Rumination as a predictor of relapse in mindfulness-based cognitive therapy for depression. Psychology and Psychotherapy, 84(2), 230-236. https://doi.org/10.1348/147608310X520166

Muarifah, A. (2012). Hubungan Kecemasan dan Agresivitas. HUMANITAS: Indonesian Psychological Journal, 2(2), 102-112-112. https://doi.org/10.26555/humanitas.v2i2.319

Murni, N. N. A., Suhartono, S., \& Suherni, T. (2014). Pengaruh Latihan Relaksasi Guided Imagery and Music (Gim) pada Kelas Ibu Terhadap Derajat Kecemasan Ibu Hamil Menghadapi Persalinan Pertama: Studi Di Puskesmas Meninting Kabupaten Lombok. Jurnal Kesehatan Prima, 8(1), 1197-1206.

Nurlaila, S. (2011). Pelatihan Efikasi Diri untuk Menurunkan Kecemasan pada Siswa-Siswi yang Akan Menghadapi Ujian Akhir Nasional. GUIDENA: Jurnal Ilmu Pendidikan, $\begin{array}{lllll}\text { Psikologi, Bimbingan } & \text { Konseling, }\end{array}$ https://doi.org/10.24127/gdn.v1i1.348

O'Leary, K. (2015). The effect of positive psychological interventions on psychological and physical well-being during pregnancy [Doctoral thesis, University College Cork]. https://cora.ucc.ie/handle/10468/2118

Orsillo, S. M., \& Roemer, L. (2011). The mindful way through anxiety: Break free from chronic worry and reclaim your life. Guilford Press.

Pratiwi, I., \& Suwarti, S. (2013). Pengaruh Komunikasi Dokter Pasien terhadap Kecemasan Pasca Melahirkan dengan Tindakan Sectio Caesarea di RSUD. Prof. Dr. Margono Soekarjo Purwokerto. Psycho Idea, 11(1). https://doi.org/10.30595/psychoidea.v11i1.253

Roemer, L., \& Orsillo, S. M. (2006). Expanding Our Conceptualization of and Treatment for Generalized Anxiety Disorder: Integrating Mindfulness/Acceptance-Based Approaches With Existing Cognitive-Behavioral Models. Clinical Psychology: Science and Practice, 9(1), 54-68. https://doi.org/10.1093/clipsy.9.1.54 
Rubertsson, C., Hellström, J., Cross, M., \& Sydsjö, G. (2014). Anxiety in early pregnancy: Prevalence and contributing factors. Archives of Women's Mental Health, 17(3), 221-228. https://doi.org/10.1007/s00737-013-0409-0

Segal, Z. V., Williams, J. M. G., Teasdale, J. D., \& Kabat-Zinn, J. (2018). Mindfulness-based cognitive therapy for depression.

Tull, M. T., Stipelman, B. A., Salters-Pedneault, K., \& Gratz, K. L. (2009). An examination of recent non-clinical panic attacks, panic disorder, anxiety sensitivity, and emotion regulation difficulties in the prediction of generalized anxiety disorder in an analogue sample. Journal of Anxiety Disorders, 23(2), 275-282. https://doi.org/10.1016/j.janxdis.2008.08.002

Udechuku, A., Nguyen, T., Hill, R., \& Szego, K. (2010). Antidepressants in pregnancy: A systematic review. The Australian and New Zealand Journal of Psychiatry, 44(11), 978-996. https://doi.org/10.3109/00048674.2010.507543

Utomo, Y. D. C., \& Sudjiwanati, S. (2018). Pengaruh Dukungan Sosial Terhadap Tingkat Kecemasan Ibu Hamil Di Rumah Sakit Bersalin Pemerintah Kota Malang. PSIKOVIDYA, 22(2), 197-223. https://doi.org/10.37303/psikovidya.v22i2.117

Wenzel, A. (2011). Anxiety in childbearing women: Diagnosis and treatment. American Psychological Association. http://public.ebookcentral.proquest.com/choice/publicfullrecord.aspx?p=311488 6 